\title{
Water Quality of Havsa Stream Basin Creeks (Thrace Region, Turkey)
}

\author{
Cem Tokatli ${ }^{1, *}$, Yasin Baştatli ${ }^{2}$ \\ ${ }^{1}$ Trakya University, Ipsala Vocational School, Department of Laboratory Technology, \\ Ipsala/Edirne, Turkey \\ ${ }^{2}$ Dumlupinar University, Faculty of Science, Department of Biology, Kütahya, Turkey
}

Received 12 September 2016

Revised 22 April 2017; Accepted 28 June 2017

\begin{abstract}
Havsa Stream is located on north - west part of Marmara Region and it is one of the most important branches of Ergene River. As many aquatic habitat Havsa Stream is also under effect of an intensive agricultural pressure. In this study, water quality of Süloğlu, Hasköy, Aşağıova, Havsa, Kuleli and Anadere Creeks that are the significant components of Havsa Steam Basin were investigated. Water samples were collected in spring season of 2016 and total of 13 water quality parameters ( $\mathrm{pH}$, conductivity, TDS, salinity, turbidity, nitrate, nitrite, phosphate, sulfate, biological oxygen demand, total carbon, total inorganic carbon and total organic carbon) were investigated. Also Cluster Analysis (CA) was applied to detected data in order to classify the creeks in terms of pollution levels. According to detected data, pollution levels of the investigated creeks in parallel to the flow directions as follows; Süloğlu $>$ Hasköy $>$ Așağıvova $>$ Havsa $>$ Kuleli $>$ Anadere in general. According to the results of CA, 3 statistically significant clusters were formed, which were corresponded to Süloğlu and Hasköy (Cluster 1) that were located on the upstream; Kuleli, Havsa and Aşağıova (Cluster 2) that were located on the middlestream; Anadere (Cluster 3) that was located on the downstream.
\end{abstract}

Keywords: Süloğlu, Hasköy, Aşağıva, Havsa, Kuleli, Anadere, Creeks, Water Quality.

\section{Introduction}

Developments of industry and rapid growth of population cause lots of environmental problems and they are decreasing the limited usable freshwater potential of the world and mankind. It is known that lotic ecosystems play an important role as a receiving environment for many pollutants. Therefore water quality

\footnotetext{
*Corresponding author. Email: tokatlicem@gmail.com https://doi.org/10.25073/2588-1094/vnuees.4103
}

monitoring of these aquatic ecosystems help to assess the contamination sources of the systems and provide an effective management of these significant freshwater resources [1-5].

The Meriç River with a length of about 500 $\mathrm{km}$ is the longest river ecosystem of the Balkans. The Ergene River, which is known as the chief tributary of Meriç River Basin, is subjected to strong anthropogenic impacts as it passes through plenty of settlement areas, along industrial enterprises, farms and areas with intensive agriculture. The creeks of Havsa Stream Basin are one of the most important 
branches of Ergene River. Intense agricultural applications and settlement areas located on the basin are known as the main pollution factors for the Havsa Stream Basin [5-7].

The aim of this study was to evaluate the water quality of Havsa Stream Basin creeks by determining some limnologic parameters including $\mathrm{pH}$, electrical conductivity (EC), total dissolved solid (TDS), salinity, turbidity, Nitrate nitrogen $\left(\mathrm{NO}_{3}\right)$, nitrite nitrogen $\left(\mathrm{NO}_{2}\right)$, sulphate $\left(\mathrm{SO}_{4}\right)$, phosphate $\left(\mathrm{PO}_{4}\right)$, total carbon (TC), total inorganic carbon (TIC), total organic carbon (TOC) and biological oxygen demand (BOD) and classify the creeks according to water quality statuses by using Cluster Analysis (CA).

\section{Materials and methods}

\subsection{Study area and collection of samples}

The study area and selected stations on the Havsa Stream Basin are given in Figure 1. Coordinate information, some explanations and the localities of selected stations are given in Table 1. Water samples (one sample per location) were collected in spring season of 2016.

Table 1. Location properties of selected stations

\begin{tabular}{llllll}
\hline Station & \multirow{2}{*}{ Locality } & \multirow{2}{*}{ Main Pollution Source [8] } & \multicolumn{2}{l}{ Coordinates } & Name of \\
\cline { 5 - 5 } & & & North & South & Creek \\
\hline 1. St. & Süloğlu District & Urban Sewage & 41.781437 & 26.916385 & Süloğlu \\
2. St. & Arpaç Village & Agricultural drainage & 41.691578 & 26.881502 & Hasköy \\
3. St. & Havsa District & Urban Sewage & 41.548334 & 26.824100 & Aşağıva \\
4. St. & Tahal Village & Agricultural drainage & 41.426217 & 26.851837 & Havsa \\
5. St. & Kuştepe Village & Agricultural drainage & 41.368404 & 26.959886 & Kuleli \\
6. St. & Input of Ergene River & Agricultural drainage & 41.344102 & 26.883712 & Anadere \\
\hline
\end{tabular}

\subsection{Physicochemical analysis}

Measurements of $\mathrm{pH}$, electrical conductivity (EC), total dissolved solid (TDS) and salinity parameters were performed by using Hach branded (HQ40D) Portable Multi Parameter Measurement Device and turbidity parameter was performed by using Hach branded (2100Q) Portable Turbidimeter Device during the field studies. Nitrate nitrogen $\left(\mathrm{NO}_{3}\right)$, nitrite nitrogen $\left(\mathrm{NO}_{2}\right)$, sulphate $\left(\mathrm{SO}_{4}\right)$, phosphate $\left(\mathrm{PO}_{4}\right)$, total carbon (TC), total inorganic carbon (TIC) and total organic carbon (TOC) parameters were performed by using Hach branded (DR3900) Spectrophotometer Device and biological oxygen demand (BOD) parameter was performed by using Hach branded (BOD Trak II) BOD Device during the laboratory studies [9-15].

\subsection{Statistical analysis}

Bray Curtis similarity is a non - metric coefficient particularly common in ecology for the quantitative and qualitative standardized variables. Cluster Analysis (CA) with the paired group algorithm according to Bray Curtis, which was applied in order to classify the investigated streams according to water quality characteristics, and Similarity and Distance Index (SDI) according to Bray Curtis, which was applied in order to determine the similarity coefficients of streams, were applied to detected data by using PAST statistical packed program. All the investigated psychochemical data were used by entering the software at the same time [16]. 


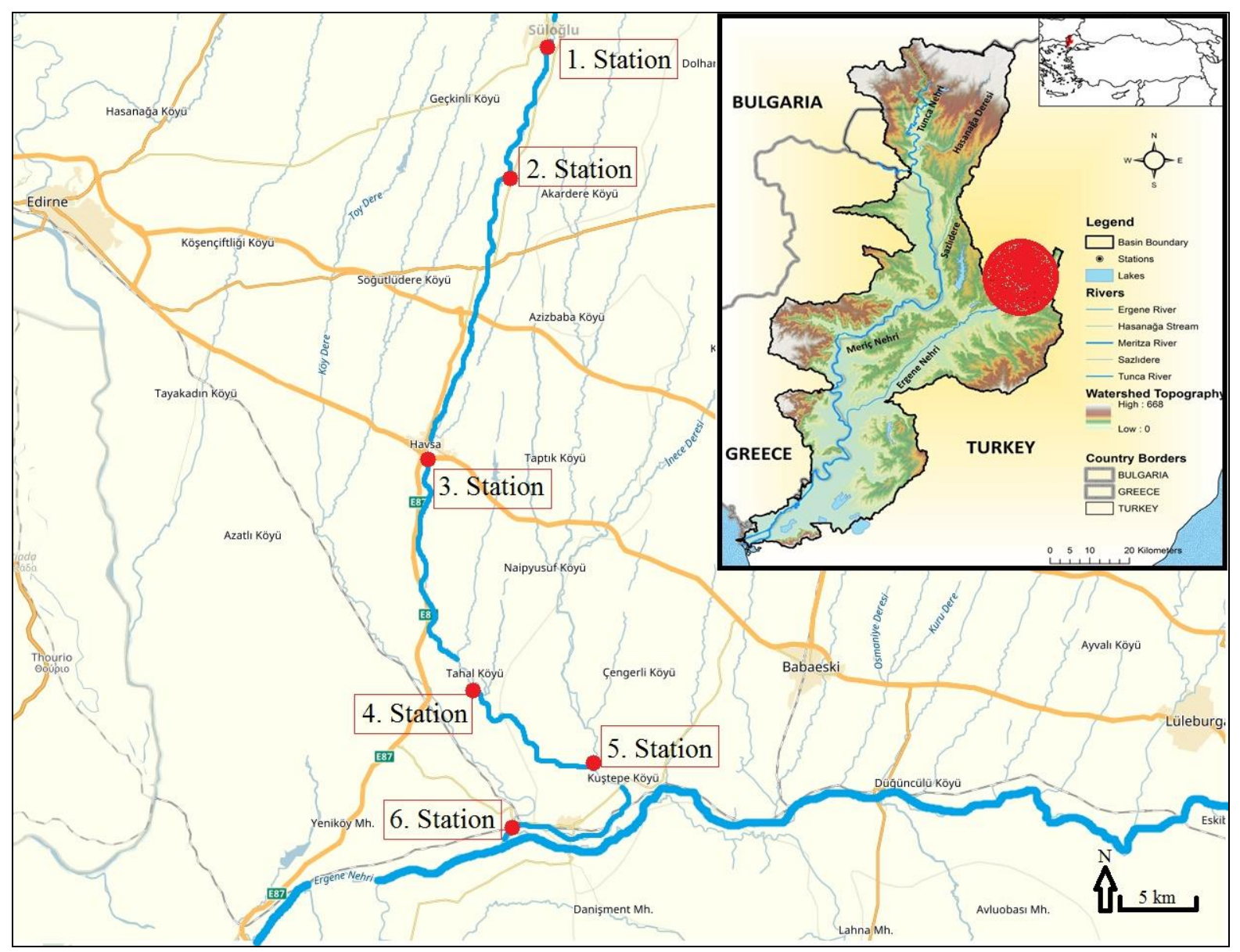

Figure 1. Havsa Stream and selected stations.

\section{Result and discussion}

The detected water quality parameters in Havsa Stream Basin creeks and some national international limit values are given in Table 1.

Most ecosystems are sensitive to changes in $\mathrm{pH}$ and the monitoring of this parameter has been incorporated into the environmental laws of many industrialized countries. Extreme changes in $\mathrm{pH}$ values in surface water can be indicative of an industrial contamination [17]. Havsa Stream Basin has an alkaline water characteristics in general and $\mathrm{pH}$ data in water of investigated stations were recorded between the values of 8.01 (in Kuleli Creek) - 8.29 (in Süloğlu Creek). According to the Turkish
Regulations, the basin has I. Class water quality in terms of $\mathrm{pH}$ values and any investigated stations did not exceed the drinking water and fish health limits [18-21].

Electrical Conductivity (EC) is the normalized measure of the ability of water to conduct electric current in natural waters. This is mostly influenced by dissolved salts like sodium chloride and potassium chloride [17]. The highest EC value in Havsa Stream Basin was recorded in Anadere Creek as $742 \mu \mathrm{s} / \mathrm{cm}$. According to the Turkish Regulations, the basin has I. Class water quality in terms of EC values and any investigated stations did not exceed the drinking water limits [18-21]. 
Table 1. Results of detected parameters and some limit values

\begin{tabular}{|c|c|c|c|c|c|c|c|c|c|c|c|c|c|c|}
\hline \multirow{2}{*}{\multicolumn{2}{|c|}{$\begin{array}{l}\text { Limit Values and } \\
\text { the Results of Present Study }\end{array}$}} & \multicolumn{13}{|c|}{ Parameters } \\
\hline & & $\mathrm{pH}$ & $\begin{array}{l}\mathrm{EC} \\
(\mathrm{mS} / \mathrm{cm})\end{array}$ & $\begin{array}{l}{ }^{\mathrm{a}} \mathrm{TDS} \\
(\mathrm{mg} / \mathrm{L})\end{array}$ & $\begin{array}{l}\text { Salinity } \\
(\%)\end{array}$ & $\begin{array}{l}\text { Tur } \\
\text { (NTU) }\end{array}$ & $\begin{array}{l}\mathrm{NO}_{3} \\
(\mathrm{mg} / \mathrm{L})\end{array}$ & $\begin{array}{l}\mathrm{NO}_{2} \\
(\mathrm{mg} / \mathrm{L})\end{array}$ & $\begin{array}{l}\mathrm{SO}_{4} \\
(\mathrm{mg} / \mathrm{L})\end{array}$ & $\begin{array}{l}{ }^{\mathrm{b}} \mathrm{PO}_{4} \\
(\mathrm{mg} / \mathrm{L})\end{array}$ & $\begin{array}{l}\mathrm{TC} \\
(\mathrm{mg} / \mathrm{L})\end{array}$ & $\begin{array}{l}\mathrm{TIC} \\
(\mathrm{mg} / \mathrm{L})\end{array}$ & $\begin{array}{l}\text { TOC } \\
(\mathrm{mg} / \mathrm{L})\end{array}$ & $\begin{array}{l}\mathrm{BOD} \\
(\mathrm{mg} / \mathrm{L})\end{array}$ \\
\hline \multirow{4}{*}{$\begin{array}{l}\text { *Turkish } \\
\text { Regulations } \\
\text { Water Quality } \\
\text { Classes } \\
{[18]}\end{array}$} & $\begin{array}{l}\text { I. Class } \\
\text { (Very Clean) }\end{array}$ & $6.5-8.5$ & 400 & 500 & - & - & 5 & 0.002 & 200 & 0.02 & - & - & 5 & 4 \\
\hline & $\begin{array}{l}\text { II. Class } \\
\text { (Less Contaminated) }\end{array}$ & $6.5-8.5$ & 1000 & 1500 & - & - & 10 & 0.01 & 200 & 0.16 & - & - & 8 & 8 \\
\hline & $\begin{array}{l}\text { III. Class } \\
\text { (Much Contaminated) }\end{array}$ & $6.0-9.0$ & 3000 & 5000 & - & - & 20 & 0.05 & 400 & 0.65 & - & - & 12 & 20 \\
\hline & $\begin{array}{l}\text { IV. Class } \\
\text { (Extremely Contaminated) }\end{array}$ & $\begin{array}{l}\text { Out of } \\
6.0-9.0\end{array}$ & $>3000$ & $>5000$ & - & - & $>20$ & $>0.05$ & $>400$ & $>0.65$ & - & - & $>12$ & $>20$ \\
\hline Drinking & TS266 [19] & $6.5-9.5$ & 2500 & - & - & 5 & 50 & 0.5 & 250 & - & - & - & - & - \\
\hline Water & $\mathrm{EC}[21]$ & $6.5-9.5$ & 2500 & - & - & - & 50 & 0.5 & 250 & - & - & - & - & - \\
\hline Standards & WHO [26] & - & - & - & - & - & 50 & 0.2 & - & - & - & - & - & - \\
\hline EC Fish Health & EC/C (Cyprinides) & $6-9$ & & 25 & - & - & - & 0.03 & - & - & - & - & - & 6 \\
\hline \multirow[t]{3}{*}{ Standards [20] } & EC/S (Salmonides) & $6-9$ & - & 25 & - & - & - & $\begin{array}{l}0.01 \\
0.004\end{array}$ & - & $\overline{-} .75$ & - & - & - & $\begin{array}{l}3 \\
27\end{array}$ \\
\hline & Süloğlu (1. St.) & $\begin{array}{l}8.29 \\
\text { I. Class }\end{array}$ & $\begin{array}{l}310 \\
\text { I. Class }\end{array}$ & $\begin{array}{l}148 \\
\text { I. Class }\end{array}$ & 0.15 & 4.73 & $\begin{array}{l}0.9 \\
\text { I. Class }\end{array}$ & $\begin{array}{l}\text { II. } \\
\text { Class } \\
0.006\end{array}$ & $\begin{array}{l}19 \\
\text { I. Class }\end{array}$ & $\begin{array}{l}\text { IV. } \\
\text { Class } \\
0.13\end{array}$ & 23.4 & 21.1 & $\begin{array}{l}2.32 \\
\text { I. Class }\end{array}$ & $\begin{array}{l}\text { IV. } \\
\text { Class }\end{array}$ \\
\hline & Hasköy (2. St.) & $\begin{array}{l}8.28 \\
\text { I. Class }\end{array}$ & $\begin{array}{l}315 \\
\text { I. Class }\end{array}$ & $\begin{array}{l}151 \\
\text { I. Class }\end{array}$ & 0.16 & 25.8 & $\begin{array}{l}1 \\
\text { I. Class }\end{array}$ & $\begin{array}{l}\text { II. } \\
\text { Class }\end{array}$ & $\begin{array}{l}22 \\
\text { I. Class }\end{array}$ & $\begin{array}{l}\text { II. } \\
\text { Class } \\
0.82\end{array}$ & 25.3 & 22.6 & $\begin{array}{l}2.72 \\
\text { I. Class }\end{array}$ & $\begin{array}{l}4.7 \\
\text { II. Class }\end{array}$ \\
\hline \multirow{4}{*}{$\begin{array}{l}\text { Havsa } \\
\text { Stream } \\
\text { Basin } \\
\text { Creeks }\end{array}$} & Aşağıova (3. St.) & $\begin{array}{l}8.27 \\
\text { I. Class }\end{array}$ & $\begin{array}{l}339 \\
\text { I. Class }\end{array}$ & $\begin{array}{l}162 \\
\text { I. Class }\end{array}$ & 0.16 & 53.5 & $\begin{array}{l}0.4 \\
\text { I. Class }\end{array}$ & $\begin{array}{l}0.001 \\
\text { I. Class } \\
0.061\end{array}$ & $\begin{array}{l}22 \\
\text { I. Class }\end{array}$ & $\begin{array}{l}\text { IV. } \\
\text { Class } \\
0.78\end{array}$ & 26.3 & 22.6 & $\begin{array}{l}2.72 \\
\text { I. Class }\end{array}$ & $\begin{array}{l}5.3 \\
\text { II. Class } \\
9.8\end{array}$ \\
\hline & Havsa (4. St.) & $\begin{array}{l}8.03 \\
\text { I. Class }\end{array}$ & $\begin{array}{l}340 \\
\text { I. Class }\end{array}$ & $\begin{array}{l}163 \\
\text { I. Class }\end{array}$ & 0.16 & 54.8 & $\begin{array}{l}0.8 \\
\text { I. Class }\end{array}$ & $\begin{array}{l}\text { IV. } \\
\text { Class } \\
0.012\end{array}$ & $\begin{array}{l}24 \\
\text { I. Class }\end{array}$ & $\begin{array}{l}\text { IV. } \\
\text { Class } \\
0.95\end{array}$ & 26.2 & 25.4 & $\begin{array}{l}0.763 \\
\text { I. Class }\end{array}$ & $\begin{array}{l}\text { III. } \\
\text { Class }\end{array}$ \\
\hline & Kuleli (5. St.) & $\begin{array}{l}8.01 \\
\text { I. Class }\end{array}$ & $\begin{array}{l}364 \\
\text { I. Class }\end{array}$ & $\begin{array}{l}175 \\
\text { I. Class }\end{array}$ & 0.17 & 44.6 & $\begin{array}{l}1.3 \\
\text { I. Class }\end{array}$ & $\begin{array}{l}\text { III. } \\
\text { Class } \\
0.042\end{array}$ & $\begin{array}{l}22 \\
\text { I. Class }\end{array}$ & $\begin{array}{l}\text { IV. } \\
\text { Class } \\
0.3\end{array}$ & 28.3 & 27.4 & $\begin{array}{l}0.954 \\
\text { I. Class }\end{array}$ & $\begin{array}{l}5.2 \\
\text { II. Class }\end{array}$ \\
\hline & Anadere (6. St.) & $\begin{array}{l}8.24 \\
\text { I. Class }\end{array}$ & $\begin{array}{l}742 \\
\text { I. Class }\end{array}$ & $\begin{array}{l}362 \\
\text { I. Class }\end{array}$ & 0.36 & 28.3 & $\begin{array}{l}1.2 \\
\text { I. Class }\end{array}$ & $\begin{array}{l}\text { III. } \\
\text { Class }\end{array}$ & $\begin{array}{l}88 \\
\text { I. Class }\end{array}$ & $\begin{array}{l}\text { III. } \\
\text { Class }\end{array}$ & 43 & 40.2 & $\begin{array}{l}2.78 \\
\text { I. Class }\end{array}$ & $\begin{array}{l}4.3 \\
\text { II. Class }\end{array}$ \\
\hline
\end{tabular}

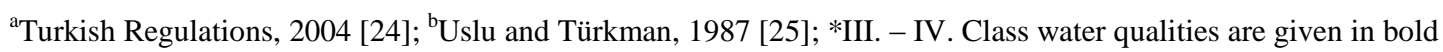
TS266 - Turkish Standards Institute; EC - European Communities; WHO - World Health Organization 
Total Dissolved Solids (TDS), which is defined as the quantity of dissolved material in water, depends mainly on the solubility of rocks and soils that the water contacts. Also salinity is defined as the total of all salts dissolved in water. It is known that settlement sewage wastes and irrigation practices in agricultural applications could raise the levels of TDS and salinity because of the presence of phosphate and nitrate [5, 22, 23]. The highest TDS and salinity levels were determined in Anadere Creek as $362 \mathrm{mg} / \mathrm{L}$ and $0.36 \%$. Although all the investigated stations have I. Class water quality in terms of TDS values [24], the recorded TDS and salinity levels in the downstream were significantly higher that detected in the upstream. Also all the detected TDS levels in all creeks were significantly higher than the limits reported for the fish health [20].

According to the Water Pollution Control Regulation criteria in Turkey [18], Havsa Stream Basin creeks have I. Class water quality in terms of nitrate, sulphate and TOC parameters and nitrate and sulphate concentrations in water of the basin did not exceed the drinking water limits $[19,21]$. But nitrite and phosphate contents in water of Havsa Stream Basin creeks were recorded in very high levels. Upstream stations have II. - III. Class and downstream stations have III. - IV. Class water quality in terms of nitrite parameter and the entire basin has III. - IV. Class water quality in terms of phosphate parameter in general $[18,25]$. Also the detected nitrite levels in downstream were significantly higher than the limit values reported for the fish health [20]. Nitrite is known as an intermediate product in the biological oxidation process reaching from ammonium to nitrate. It can reach to high concentrations in especially organically polluted waters. Also organic and inorganic fertilizers and settlement wastewater discharges are the most important factors on the amount of phosphate $[5,22,23]$.

Biological Oxygen Demand (BOD) is known as a significant microbiologic parameter.
It helps to expresses the amount of dissolved oxygen needed by aerobic biological organisms to break down the organic materials in aquatic systems [5, 22, 23]. According to the EC directives reported by the European Commission in order to protect the health of fishes in freshwater, BOD levels in freshwater must be under $6 \mathrm{mg} / \mathrm{L}$ for cyprinid species and must be under $3 \mathrm{mg} / \mathrm{L}$ for salmonid species [20]. In this study, BOD values in water of the entire basin were significantly higher than the limit values specified for salmonides and in water of Süloğlu (IV. Class water quality) Havsa (III. Class water quality) creeks were significantly higher than the limit values specified for cyprinides $[18,20]$.

Cluster Analysis (CA) is a significant group of multivariate statistical techniques and it is widely used in environmental pollution studies in order to classify the investigated areas. Hierarchical agglomerative clustering that provides intuitive similarity relationships between any one sample and the entire data set is one of the most common approaches in CA. It is typically illustrated by a dendrogram in order to provide visual summaries of the clustering processes [27-29].

CA with the paired group algorithm was used was applied to detected data to classify the creeks according to water quality characteristics. The diagram of CA calculated by using all the investigated psychochemical data was given in Figure 2. According to the results of $\mathrm{CA}$, three statistically significant clusters were formed: Cluster 1 (C1) corresponded to Süloğlu and Hasköy creeks that were located on the upstream; Cluster 2 (C2) corresponded to Kuleli, Havsa and Aşağıova creeks that were located on the middlestream; Cluster 3 (C3) corresponded to Anadere creek that was located on the downstream. Maximum similarity was observed between Aşağıova and Havsa creeks (98\%) and minimum similarity was observed between Süloğlu and Anadere creeks (57\%) (Table 2). 


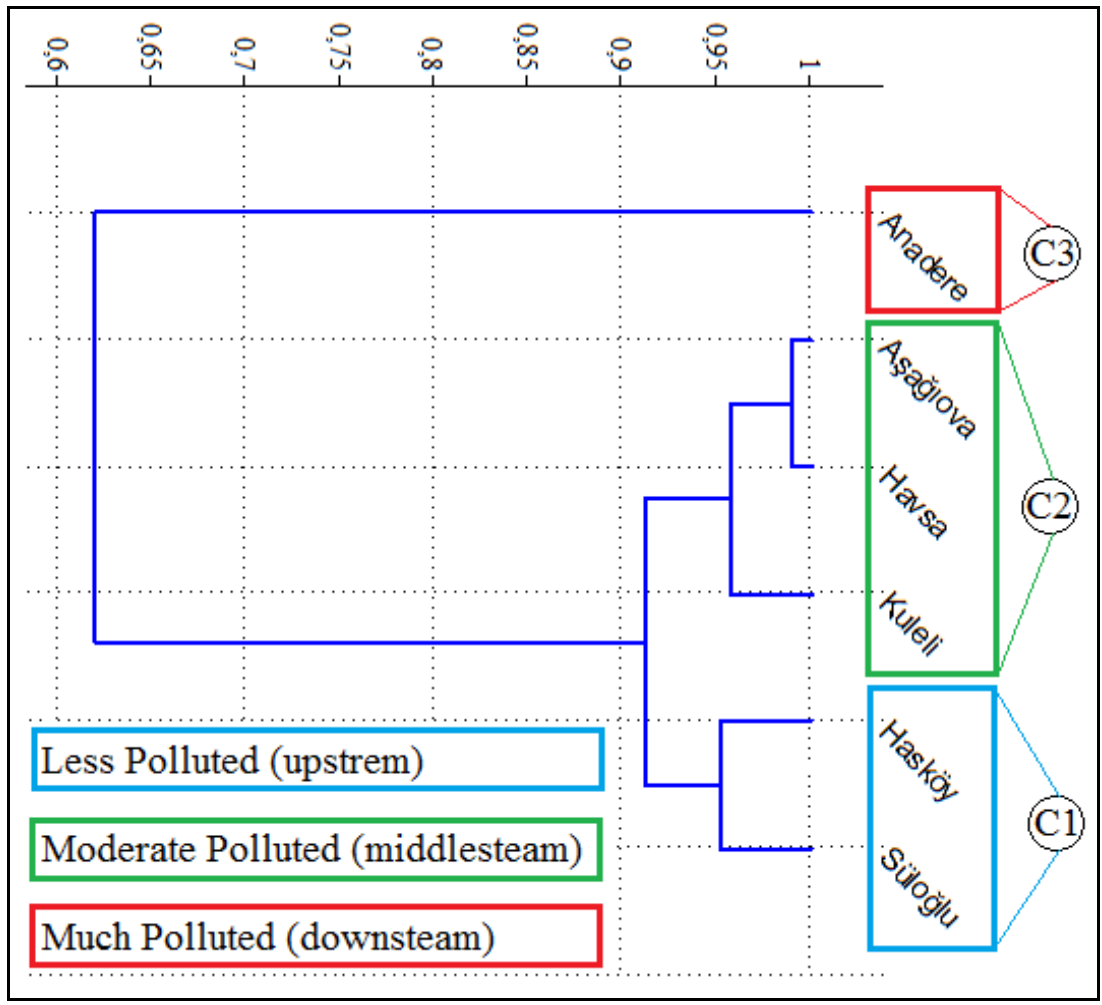

Figure 2. Diagram of CA.

Table 2. Similarity coefficients of investigated creeks

\begin{tabular}{lllllll}
\hline$*$ & Süloğlu & Hasköy & Aşağıova & Havsa & Kuleli & Anadere \\
\hline Süloğlu & 1 & & & & & \\
Hasköy & 0.95185 & 1 & & & & \\
Aşağıva & 0.90135 & 0.94652 & 1 & & & \\
Havsa & 0.8966 & 0.93728 & 0.9897 & 1 & & \\
Kuleli & 0.87409 & 0.91789 & 0.95691 & 0.95805 & 1 & \\
Anadere & 0.5762 & 0.60873 & 0.62771 & 0.63011 & 0.66043 & 1 \\
\hline
\end{tabular}

* Highest and lowest similarities are given in bold

Havsa Stream is one of the most important branches of Ergene River that is also one of the most important branches of Meriç River. Ergene River is known as a dramatically contaminated lotic ecosystem and one of the most polluted basin of Turkey [30-34]. According to the Meriç - Ergene Basin Conservation Action Plan made by Turkish Ministry of Environment and Forestry, General Directorate of Environmental Management in
2008, Havsa Stream is being adversely effected by the domestic waste sourced from especially the settlement areas around the basin, by the industrial waste sourced from especially the organized industrial zones located on the basin and by the agricultural activities conducted almost all around the region. In parallel with the literature, the results of this study show that organic contents of the system are continuous to increase and water quality of the system in 
terms of especially nitrogenous and phosphorus compounds is continuous to decrease.

\section{Conclusion}

In this study, water quality of Havsa Stream Basin creeks were evaluated by investigating some limnologic parameters. As a result of this study, it can be concluded that Havsa Stream Basin is under effect of a significant agricultural pollution and this situation cause to reduce the water quality of the system. In order to provide the sustainability of these aquatic ecosystems in terms of availability by local people, organic contents including mainly nitrite and phosphate concentrations of the creeks originated from agricultural applications must be taken under control by especially a conscious fertilizer application.

\section{References}

[1] Strobl, R. O., Robillard, P. D., 2008. Network design for water quality monitoring of surface freshwaters: a review. Journal of Environmental Management 87, 639-648.

[2] Tokatll, C., 2013. Use of Statistical Methods in Water Quality Assessment: A Case Study of Balkan Arboretum Area in Trakya University (Edirne, Turkey). Journal of Applied Biological Sciences, 7 (3): 79-83.

[3] Tokatl1, C., Köse, E., Çiçek, A., 2014. Assessment of the Effects of Large Borate Deposits on Surface Water Quality by Multi Statistical Approaches: A Case Study of The Seydisuyu Stream (Turkey). Polish Journal of Environmental Studies, 23 (5): 1741-1751.

[4] Köse, E., Çiçek, A., Uysal, K., Tokatlı, C., Emiroğlu, Ö., Arslan, N., 2015. Heavy Metal Accumulations in Water, Sediment and Some Cyprinidae Fish Species From Porsuk Stream (Turkey). Water Environment Research, 87 (3): 195-204.

[5] Tokatl1, C., 2015. Assessment of the Water Quality in the Meriç River: As an Element of the Ecosystem in the Thrace Region of Turkey. Polish Journal of Environmental Studies, 24 (5): 22052211.
[6] Tokatlı, C., Emiroğlu, Ö., Çiçek, A, Köse, E., Başkurt, S., Aksu, S., Uğurluoğlu, A., Şahin, M., Baştatl, Y., 2016. Investigation of Toxic Metal Bioaccumulations in Fishes of Meriç River Delta (Edirne). Anadolu University Journal of Science and Technology - $\mathrm{C}$ Life Sciences and Biotechnology, 5 (1): 1-11.

[7] Tokatlı, C., Baştatlı, Y., 2016. Trace and Toxic Element Levels in River Sediments. Polish Journal of Environmental Studies, 25 (4): 17151720.

[8] Anonymous, 2008. Turkish Ministry of Environment and Forestry, General Directorate of Environmental Management, Meriç - Ergene Basin Conservation Action Plan.

[9] EN ISO 10304-1. Water quality "Determination of dissolved anions by liquid chromatography of ions": Determination of chloride and nitrate.

[10] EN ISO 10304-2. Water quality "Determination of dissolved anions by liquid chromatography of ions": Determination of sulfate.

[11] EN ISO 26777. Water quality "Determination of dissolved anions by liquid chromatography of ions": Determination of nitrite.

[12] DIN 38405-D5. German standard methods for the examination of water, waste water and sludge; anions (group D); determination of sulfate (D5).

[13] DIN 38406-E6. German standard methods for the examination of water, waste water and sludge; anions (group E); determination of ammonium (E5).

[14] DIN 38405 D9-2. German standard methods for the examination of water, waste water and sludge; anions (group D); determination of nitrate (D9-2).

[15] DIN 38409 H41-H44. German standard methods for the examination of water, waste water and sludge; anions (group $\mathrm{H}$ ); determination of chemical oxygen demand (H41-H44).

[16] Kaufman, L., Rousseeuw, P. J., 2009. Finding groups in data: an introduction to cluster analysis. Wiley Interscience Publishing Group.

[17] Ugwu, A. I., Wakawa, R. J., 2012. A study of seasonal physicochemical parameters in River Usma, American Journal of Environmental Science, 2012, 8 (5): 569-576.

[18] Turkish Regulations, 2012. Yüzeysel Su Kalitesi Yönetimi Yönetmeliği, 30 Kasım 2012 tarihli Resmi Gazete, Sayl: 28483, http://suyonetimiormansu.gov.tr.

[19] TS 266, 2005. Sular-İnsani tüketim amaçlı sular. Türk Standartları Enstitüsü, ICS 13.060.20. 
[20] EC (European Communities), 2006. EC of the European Parliament and of the council of 6 September 2006 on the quality of fresh waters needing protection or improvement in order to support fish life. Directive 2006/44.

[21] EC (European Communities), 2007. European Communities (drinking water) (no. 2), Regulations 2007, S.I. No. 278 of 2007.

[22] Wetzel, R. G. 2001. Limnology: Lake and River Ecosystems. Elsevier Academic Press, 1006 pages.

[23] Manahan, S. E. 2011. Water Chemistry: Green Science and Technology of Nature's Most Renewable Resource. Taylor \& Francis Group, CRC Press, 398 pages.

[24] Turkish Regulations, 2004. Yüzeysel Su Kalitesi Yönetimi Yönetmeliği, 31 Aralık Cuma tarihli Resmi Gazete, Sayı: 25687, http://suyonetimiormansu.gov.tr.

[25] Uslu, O., Türkman, A., 1987. Su Kirliliği ve Kontrolü. T.C. Başbakanlık Çevre Genel Müdürlügü Yayınları, Eğitim Dizisi I, Ankara.

[26] WHO (World Health Organization), 2011. Guidelines for Drinking-water Quality. World Health Organization Library Cataloguing-inPublication Data, NLM classification: WA 675.

[27] Shrestha S., Kazama F., 2007. Assessment of surface water quality using multivariate statistical techniques: A case study of the Fuji river basin; Japan. Environmental Modelling \& Software, 22, 464-475.
[28] Tokatl1, C., Çiçek, A., Köse, E., 2013. Groundwater Quality of Türkmen Mountain (Turkey). Polish Journal of Environmental Studies, 22 (4), 1197-1208.

[29] Tabachnick, B. G., Fidell L. S., 1996. Using multivariate statistics (3rd ed.). New York: Harper Collins College Publishers.

[30] Edirne (2005). Edirne İl Çevre Durum Raporu. Edirne Valiliği İl Çevre Ve Orman Müdürlügüü.

[31] Tokatlı, C., Köse, E., Uğurluoğlu, A., Çiçek, A., Emiroğlu, Ö., 2014. Gala Gölü (Edirne) Su Kalitesinin Coğrafi Bilgi Sistemi (CBS) Kullanılarak Değerlendirilmesi. Sigma Journal of Engineering and Natural Sciences, 32: 490-501.

[32] Arda, H., Helvacioğlu, İ. A., Meriç, Ç., Tokatlı, C., 2015. Investigation on the Heavy Metal Contents in Irrigation Water of Ipsala District. Journal of Tekirdag Agricultural Faculty, 12 (3): 1-7.

[33] Tokatlı, C., Baştatlı, Y., 2016. Assessment of Toxic Metals in Sediments of Meriç, Tunca and Ergene Rivers by Using Biological and Ecological Risk Indices. Central Bohemia University International Conference on Innovations in Science and Education, 23-25 March 2016, Prague, Czech Republic, 770-775.

[34] Tokatl1, C., 2017. Bio - Ecological and Statistical Risk Assessment of Toxic Metals in Sediments of a Worldwide Important Wetland: Gala Lake National Park (Turkey). Archives of Environmental Protection, 43 (1): 34-47.

\title{
Chất lượng nước của lưu vực đầm lầy Havsa (Vùng Thrace, Thổ Nhĩ Kỳ)
}

\author{
Cem Tokatli ${ }^{1}$, Yasin Baştatlii ${ }^{2}$ \\ ${ }^{\text {I} Đ a ̣ i ~ h o ̣ c ~ T r a k y a ~ U n i v e r s i t y, ~ T r u o ̀ n g ~ H u ̛ o ̛ ́ n g ~ n g h i e ̣ ̂ p ~ I p s a l a, ~ P h o ̀ n g ~ C o ̂ n g ~ n g h e ̣ ̂ ~ T h i ́ ~ n g h i e ̣ ̂ m, ~}$ \\ Ipsala/Edirne, Thổ Nhĩ Kỳ \\ ${ }^{2}$ Đại học Dumlupinar, Khoa Khoa học, Bộ môn Sinh học, Kütahya, Thổ Nhĩ Kỳ
}

Tóm tắt: Dòng Havsa nằm ở phía Tây bắc của vùng Marmara và là một trong những nhánh quan trọng nhất của sông Ergene. Bởi vì có rất nhiều sinh cảnh dưới nước nên dòng Havsa cũng chịu ảnh hưởng của áp lực nông nghiệp thâm canh. Trong nghiên cứu này, chất lượng nước của vùng Süloğlu, Hasköy, Aşağıova, Havsa, Kuleli và Anadere Creeks là hợp phần quan trọng của lưu vực Havsa cũng 
được điều tra. Các mẫu nước được thu thập vào mùa xuân năm 2016 và tổng số 13 tham số chất lượng nước ( $\mathrm{pH}$, độ dẫn, TDS, độ mặn, độ đục, nitrat, nitrit, phosphate, sulfat, nhu cầu oxy sinh học, tổng carbon, carbon vô cơ tổng hợp và carbon hữu cơ tổng hợp) đã được nghiên cứu. Phân tích nhóm cũng được sử dụng để phát hiện dữ liệu, phân loại các lạch về mức độ ô nhiễm. Theo số liệu điều tra, mức độ ô nhiễm của các dòng sông được điều tra song song với hướng dòng chảy như sau; Süloğlu> Hasköy $>$ Aşağıova $>$ Havsa $>$ Kuleli $>$ Anadere nói chung. Theo kết quả phân tích nhóm, 3 nhóm có ý nghĩa thống kê đã được hình thành, tương ứng với Süloğlu và Hasköy (nhóm 1) nằm ở thượng nguồn; Kuleli, Havsa và Aşağı

Tù̀ khoá: Süloğlu, Hasköy, Aşağıova, Havsa, Kuleli, Anadere, Creeks, chất lượng nước. 